\title{
Associations between novel single nucleotide polymorphisms in the Bos taurus growth hormone gene and performance traits in Holstein-Friesian dairy cattle
}

\author{
M. P. Mullen, ${ }^{\star 1}$ D. P. Berry,† D. J. Howard, ${ }^{\star}$ M. G. Diskin, ${ }^{\star}$ C. O. Lynch, ${ }^{\star}$ E. W. Berkowicz,‡ D. A. Magee,‡ \\ D. E. MacHugh, $¥ \S$ and S. M. Waters\# \\ *Animal and Bioscience Research Department, Animal and Grassland Research and Innovation Centre, Teagasc, Mellows Campus, Athenry, \\ Co. Galway, Ireland \\ †Animal and Bioscience Research Department, Animal and Grassland Research and Innovation Centre, Teagasc, Moorepark, Fermoy, \\ Co. Cork, Ireland \\ ҒAnimal Genomics Laboratory, School of Agriculture, Food Science and Veterinary Medicine, College of Life Sciences, University College Dublin, \\ Belfield, Dublin 4, Ireland \\ §UCD Conway Institute of Biomolecular and Biomedical Research, University College Dublin, Dublin 4, Ireland \\ \#Animal and Bioscience Research Department, Animal and Grassland Research and Innovation Centre, Teagasc, Grange, Dunsany, Co. Meath, \\ Ireland
}

\section{ABSTRACT}

Growth hormone, produced in the anterior pituitary gland, stimulates the release of insulin-like growth factor-I from the liver and is of critical importance in the control of nutrient utilization and partitioning for lactogenesis, fertility, growth, and development in cattle. The aim of this study was to discover novel polymorphisms in the bovine growth hormone gene (GH1) and to quantify their association with performance using estimates of genetic merit on 848 Holstein-Friesian AI (artificial insemination) dairy sires. Associations with previously reported polymorphisms in the bovine GH1 gene were also undertaken. A total of 38 novel single nucleotide polymorphisms (SNP) were identified across a panel of 22 beef and dairy cattle by sequence analysis of the $5^{\prime}$ promoter, intronic, exonic, and $3^{\prime}$ regulatory regions, encompassing approximately $7 \mathrm{~kb}$ of the GH1 gene. Following multiple regression analysis on all SNP, associations were identified between 11 SNP (2 novel and 9 previously identified) and milk fat and protein yield, milk composition, somatic cell score, survival, body condition score, and body size. The G allele of a previously identified SNP in exon 5 at position 2141 of the GH1 sequence, resulting in a nonsynonymous substitution, was associated with decreased milk protein yield. The C allele of a novel SNP, GH32, was associated with inferior carcass conformation. In addition, the $\mathrm{T}$ allele of a previously characterized SNP, GH35, was associated with decreased survival. Both GH24 (novel) and GH35 were independently associated

Received April 28, 2010.

Accepted September 7, 2010.

${ }^{1}$ Corresponding author: Michael.Mullen@teagasc.ie with somatic cell count, and 3 SNP, GH21, 2291, and GH35, were independently associated with body depth. Furthermore, 2 SNP, GH24 and GH63, were independently associated with carcass fat. Results of this study further demonstrate the multifaceted influences of GH1 on milk production, fertility, and growth-related traits in cattle.

Key words: growth hormone, Holstein, polymorphism, performance

\section{INTRODUCTION}

Growth hormone $(\mathbf{G H})$, produced in the anterior pituitary gland, stimulates the release of IGF-I from the liver and is key in the control of nutrient utilization and partitioning (Bauman, 1992). It is a major regulator of postnatal growth and metabolism in mammals and therefore plays critical roles in the control of lactation, mammary gland development, growth processes, and fertility in cattle (Jiang and Lucy, 2001; Renaville et al., 2002; Lucy, 2008). Evidence exists for an association of genetic variants of the bovine growth hormone gene, GH1, with plasma levels of GH (Schlee et al., 1994), suggesting that at least some variation of GH level is potentially caused by mutations in the GH1 gene. It is therefore a promising candidate gene marker for improving fertility, growth, and meat and milk production in cattle.

Bovine GH is a single-chain polypeptide of approximately $23 \mathrm{kDa}$, consisting of $210 \mathrm{AA}$ residues. The gene, mapped on bovine chromosome 19, is 1,470 bp long and consists of 5 exons separated by 4 intervening sequences (http://www.ensembl.org, Btau_4.0; April 2010). Several authors have identified polymorphisms in the promoter, third and fourth introns, and fifth 
exon of GH1 (Lucy et al., 1993; Yao et al., 1996; Ge et al., 2003). Lucy et al. (1993) found that a substitution of cytosine $(\mathrm{C})$ for guanine $(\mathrm{G})$ at position 2141 caused an amino acid change from Leu to Val at residue 127 of the GH polypeptide and was associated with decreased milk yield in a mixed-breed study including Holstein, Brown Swiss, Guernsey, Jersey, and Ayrshire cattle. In addition, Schlee et al. (1994) reported that Simmental bulls with the Leu/Leu genotype had significantly higher plasma GH levels than those with the Val/Val genotype. In Japanese black cattle, 3 haplotypes that differ by amino acid mutations at positions 127 and 172 in the fifth exon, were associated with carcass weight and beef marbling score (Tatsuda et al., 2008).

Studies on the discovery of new polymorphisms in bovine $G H 1$ and their subsequent association with performance traits in cattle are lacking. Thus, the objective of this study was to identify novel SNP in GH1 and, along with known SNP, quantify their association with performance traits in Holstein-Friesian cattle using multiple regression analysis.

\section{MATERIALS AND METHODS}

\section{DNA Extraction}

Biological material for DNA extraction originated from 2 main sources: 1) blood samples from 22 cattle of differing breeds including Belgian Blue, Charolais, Simmental, and Aberdeen Angus crossbreds as well as Holstein-Friesian cattle used for SNP discovery, and 2) semen samples from 914 Holstein-Friesian AI bulls for association analysis.

A proteinase $\mathrm{K} /$ salting out/ethanol precipitation extraction method (adapted from Montgomery and Sise, 1990) was used to extract DNA from blood samples. DNA was extracted from the thawed-frozen semen using a Maxwell 16 instrument and Maxwell 16 Tissue DNA Purification Kits from Promega (Southampton, UK). Prior to DNA extraction, washed semen was incubated overnight in lysis buffer (Heyen et al., 1997). Following extraction, the quality and quantity of DNA derived from both blood and semen were assessed using a Nanodrop spectrophotometer (ThermoScientific, Waltham, MA) and agarose gel electrophoresis.

\section{Resequencing and SNP Discovery}

Single nucleotide polymorphisms in the GH1 gene (including $5 \mathrm{~kb}$ upstream and downstream of the gene to encompass promoter and regulatory regions) were identified using the ENSEMBL database (http:// www.ensembl.org; accessed April 2008) and the Btau_4.0 (October 2007) assembly (accession no. ENS-
BTAG00000011082). Bovine GH1-specific PCR primers were designed using the Primer3 program (Skaletsky, 2000) and the NCBI primer blast tool (http://www. ncbi.nlm.nih.gov/tools/primer-blast/) to amplify approximately 1,000-bp fragments of the gene flanking the SNP identified in ENSEMBL (Table 1). Cycling conditions were as follows: initial denaturation at $94^{\circ} \mathrm{C}$ for 4 min followed by 30 cycles $94^{\circ} \mathrm{C}$ for $30 \mathrm{~s}, 56^{\circ} \mathrm{C}$ for $30 \mathrm{~s}, 72^{\circ} \mathrm{C}$ for $2 \mathrm{~min}$, and a final extension step of $72^{\circ} \mathrm{C}$ for 5 min. Each PCR reaction was carried out in a final volume of $50 \mu \mathrm{L}$ and contained $20 \mathrm{ng}$ of genomic DNA, $1 \mu M$ primers, $2 \mathrm{mM} \mathrm{MgCl} 2,1 \mathrm{U}$ of Platinum Taq polymerase, and $1 \times$ Buffer Invitrogen (Invitrogen Life Sciences, Dublin, Ireland). The PCR products were purified and sequenced commercially by Eurofins MWG Operon (Martinsried, Germany). Sequence data were manually checked for quality including background noise, peak intensity, and accuracy via the chromatograms using Chromas Lite v2.01 (http:/ /www.technelysium.com.au/ chromas_lite.htm) and analyzed using the BLAST tool from NCBI to confirm their identity and position on bovine chromosome 19 (http://www.ncbi.nlm.nih.gov/ genome/seq/BlastGen/BlastGen.cgi?taxid = 9913).

Sequence alignments and identification of SNP were performed using Clustal W (Larkin et al., 2007) and Chromas Lite v2.01 programs (http://www.technelysium.com.au/chromas_lite.htm). This allowed validation of published SNP and the identification of novel SNP within and flanking the GH1 gene.

\section{Genotypic and Phenotypic Data}

All SNP identified during the resequencing process alongside additional published SNP were genotyped across 914 Holstein-Friesian AI sires. The SNP genotyping was performed commercially using the Sequenom MassArray iPLEX Gold assay (Sequenom, San Diego, CA). Quality control of genotypes was described by Waters et al. (2010). Following quality control, genotypes on 848 AI sires remained. Daughter yield deviations (expressed on the scale of PTA) and PTA, as well as associated reliabilities, were available for a range of performance traits evaluated by the Irish Cattle Breeding Federation in the January 2009 domestic genetic evaluations. Daughter yield deviations and PTA are measures of the genetic merit of an animal. Production traits included 305-d milk, fat, and protein yields as well as milk fat and protein percentages and geometric mean SCS ( $\log _{e}$ SCC). Predicted transmitting abilities were also available for calving interval, functional survival, cow carcass weight, progeny carcass weight, progeny carcass fat score, and progeny carcass conformation scores as well as linear type traits. Only the 4 type traits associated with body size were retained. 
Table 1. Nucleotide sequence and PCR product sizes for the bovine growth hormone (GH1) oligonucleotides

\begin{tabular}{|c|c|c|c|}
\hline $\begin{array}{l}\text { Primer } \\
\text { set name }\end{array}$ & Primer $^{1}$ & Sequences $\left(5^{\prime}-3^{\prime}\right)$ & $\begin{array}{l}\text { Product } \\
\text { size (bp) }\end{array}$ \\
\hline \multirow[t]{2}{*}{ GHSNP1 } & For & AGGAGTTGGTGATGGACAGG & 1,020 \\
\hline & Rev & CGCATTACCCCTTTAGGACA & \\
\hline \multirow[t]{2}{*}{ GHSNP2 } & For & ACTGCTCCTCATCCAGTCGT & 1,020 \\
\hline & Rev & TGAGTGGGGCTGGAACTAAG & \\
\hline \multirow[t]{2}{*}{ GHSNP3-7 } & For & TGATTTCATTATCCTCGAGTTCA & 1,140 \\
\hline & Rev & TCAGTCATGTCCGACTTCCA & \\
\hline \multirow[t]{2}{*}{ GHSNP8-13 } & For & ACGGCAGAAAGTGAAGAGGA & 1,080 \\
\hline & Rev & AGGGATCAAACCCAGGTCTC & \\
\hline \multirow[t]{2}{*}{ GHSNP14 } & For & CGACTGAGCGACTGATCTGA & 974 \\
\hline & Rev & CTCTGTCCATGGGGATTCTC & \\
\hline \multirow[t]{2}{*}{ GHSNP15-23 } & For & GAGCCGAGGTAGATCAGACG & 982 \\
\hline & Rev & CCTTCAGTCCACATGAGGGT & \\
\hline \multirow[t]{2}{*}{ GHSNP24-33 } & For & AGGGTACCAGTGGTGACAGC & 1,055 \\
\hline & Rev & GCAGACACTTGCTTCCATGA & \\
\hline
\end{tabular}

${ }^{1}$ For $=$ forward primer; Rev $=$ reverse primer.

Data and models used in the national genetic evaluation of these traits are described in detail by Berry et al. (2007) and summarized by Waters et al. (2010). The PTA were deregressed using the procedure outlined by Berry et al. (2009), and only sires with a reliability (less parental contribution) of $>60 \%$ for the trait under investigation were retained for inclusion in the association analyses. A total of 742 sires were used in the association analyses with milk, fat, and protein yields as well as milk fat and protein percentages; the number of sires included in the association analysis with SCS, calving interval, and survival was 703, 501, and 477, respectively. The number of sires with a reliability of $>60 \%$ for the carcass traits was 446 , and the number of sires with a reliability of $>60 \%$ for the linear type traits varied from 484 to 551 .

\section{Association Analysis}

The association between each SNP and performance was quantified using weighted mixed models in ASREML (Gilmour et al., 2009) with the relationships among genotyped bulls accounted for through the relationship matrix. The dependent variable was daughter yield deviation for milk yield, fat yield, protein yield, and SCS, and was deregressed PTA for the remaining traits, weighted by their respective reliability less the parental contribution. Year of birth (divided into 5 yearly intervals) and percentage Holstein of the bull were included as fixed effects in the model. Genotype was included in the analysis as a continuous variable coded as the number of copies of a given allele.

Regression on individual SNP were initially undertaken to identify spatial patterns of SNP associated with performance. Because of the covariances between SNP (i.e., linkage disequilibrium), and between phenotypes, traditional multiple testing adjustments that assume independence among the regressors (e.g., Bonferroni, permutation) were not appropriate. Spectral decomposition of the square root of the pairwise linkage disequilibrium between the SNP was used to determine the effective number of variables (SNP); an effective number of 8.97 SNP was identified. Furthermore, the phenotypes were grouped into 4 categories, milk production, fertility, carcass traits, linear type traits, similar to that undertaken by Banos et al. (2008). Bonferroni adjustment for multiple testing was undertaken assuming a total, therefore, of 35.89 effective independent tests (i.e., 8.97 effective SNP $\times 4$ groups of traits). Additionally, as a means of overcoming the large number of statistical tests and the potential overstringency of adjusting for multiple testing, a multiple regression model was progressively built for each trait in which more than one SNP was associated $(P<0.05)$ with the trait in the univariate analyses.

\section{Transcription Factor Binding Site and microRNA Site Analysis}

Bioinformatic analysis was carried out using the panel of SNP in the promoter regions of the GH1 gene to examine the effects of allele substitution on transcription factor binding sites predicted by the MatInspector software package (Cartharius et al., 2005). The effects of allele substitution on microRNA binding sites were analyzed using MicroInspector software (Rusinov et al., 2005).

\section{RESULTS}

\section{SNP Discovery}

In total, 63 SNP (21 from the Holstein-Friesian component of the SNP discovery panel) were identified 
through the resequencing of $G H 1$, of which 25 were previously identified either in dbSNP (http://www.ncbi. nlm.nih.gov/projects/SNP) or in the literature. The SNP identified included 41 (25 novel) in the $5^{\prime}$ untranslated region (UTR) of the GH1 gene; 7 (5 novel) in the intron between exons 4 and 5; 3 (1 novel) in exon 5; and 12 (7 novel) in the 3' UTR of GH1. To the knowledge of the authors, the existence of the 38 putative novel SNP has not been described previously; and these have been submitted to dbSNP (handle: S_WATERS_M_MULLEN, batch ID: 2009GH).

\section{SNP Summary Statistics in the Holstein-Friesian Sires}

Of the 63 SNP identified, 7 SNP [one intronic, 2017 (Gordon et al., 1983; Yao et al., 1996); one 3' UTR, rs41923480; and five 5' UTR SNP, rs41923526, GH43, GH44, GH55, and GH58] failed to generate successful primers for the genotyping process in the Holstein-Friesian bulls. Seventeen SNP [253 (Ge et al., 2003), GH7, GH8, GH9, GH11, GH12, GH13, GH15, 2567 (Lagziel and Soller, 1999), GH22, GH28, GH39, GH40, GH41, rs41923527, GH46, and GH59] identified in breeds other than Holstein-Friesian in the SNP discovery panel were monomorphic in the population of HF sires and were therefore excluded from the association analyses. In addition, 7 SNP [313 (GH3) (Ge et al., 2003), 502 (GH4) (Ge et al., 2003), GH18, GH26, GH27, GH56, and $G H 62]$ were excluded from analysis due to poor call rates. The SNP GH29 (rs41923520) and GH54 were only present in the heterozygote form and were also excluded. A further $3 \mathrm{SNP}$ (GH48, GH49, and GH50) were excluded because of minor allele frequencies (MAF) of $<0.02$. The remaining SNP, totaling 27, were segregating in the Holstein-Friesian bulls, of which 11 SNP were significantly $(P<0.05)$ associated with the performance traits analyzed in either the univariate or the multiple regression analysis. Two of these SNP were novel (GH32 and GH24), 3 were previously published, and 6 were previously identified but not tested for associations with performance traits in cattle. Nomenclature, flanking sequences, and allele frequencies including Hardy-Weinberg equilibrium statistics of these 11 SNP are described in Table 2. The MAF for the 11 segregating SNP ranged from 0.08 (303) to 0.46 (GH35). Of the 11 SNP, 6 (2141, 303, GH17, GH21, GH24, and GH38) deviated from Hardy-Weinberg equilibrium due to heterozygote deficiencies (2141, GH17, GH21, GH24, and GH38) or the absence of the minor allele in the homozygote form (303). Table 3 summarizes the extent of linkage disequilibrium (LD; $\mathrm{r}^{2}$ and $\left.\mathrm{D}^{\prime}\right)$ among the 11 SNP in the Holstein-Friesian sample population. Two blocks of LD were evident across the 26 segregating SNP; SNP GH32, GH35, GH38, and GH63 were all in moderate LD, and SNP 2291, GH17, GH19, and GH24 were also all in moderate LD, of which 2291 and GH17 were in almost complete LD. All remaining SNP were in low LD.

\section{Associations with Milk Production, SCS, Calving Interval, and Survival}

The allelic substitution effects $(P<0.1)$ on milk yield, milk composition, SCS, calving interval and survival analyzed when each SNP was individually included in the model are listed in Table 4. Clusters (i.e., 2 or more) of adjacent SNP were associated with milk fat yield, milk fat and protein percentages, and SCS. However, after accounting for multiple testing, no SNP was associated with milk production, SCS, calving interval, or survival. The associations when estimated using a multiple regression model are presented in Table 5 and are discussed below. Single nucleotide polymorphism GH19 was the only SNP associated with fat yield; only 2141 was associated with milk protein yield. The $\mathrm{T}$ allele of $G H 17$ was positively associated $(P<0.05)$ with both milk fat and protein percentages, and the $\mathrm{T}$ allele of $G H 35$ was positively associated $(P<0.05)$ with SCS. Although GH24 was not associated $(P<0.1)$ with SCS in the univariate analysis, following adjustment for the association between GH35 and SCS, the association between GH24 and SCS became significant $(P<0.05)$. The T allele of $G H 35$ was negatively associated $(P<$ 0.05) with functional survival.

\section{Associations with Carcass and Body Size Traits}

When included individually in the model, 11 SNP were associated with carcass and body size traits and only the associations with these SNP are detailed in Table 4. No SNP was associated with either cow or progeny carcass weight. Five size traits including carcass conformation, body depth, BCS, angularity, and stature were associated with 3 or more clustered or adjacent SNP. After accounting for multiple testing, only 2 associations (SNP 2141 and GH21, both with body depth) remained significantly $(P<0.05)$ associated with performance. The associations between $G H 1$ SNP and BCS and carcass traits when estimated using multiple regression models are listed in Table 5 and discussed below. One SNP, GH32, was associated $(P<$ 0.05 ) with carcass conformation located approximately $30 \mathrm{~kb}$ upstream in the $3^{\prime}$ UTR of GH1. Two SNP, GH63 and GH24, were associated $(P<0.05)$ with carcass fat. The $\mathrm{T}$ allele of $G H 38$ was negatively associated $(P$ 
Table 2. Location, nomenclature, minor allele frequency (MAF) and Hardy-Weinberg equilibrium (HWE) of 11 segregating growth hormone (GH1) SNP displaying associations with performance in Holstein-Friesian cattle

\begin{tabular}{|c|c|c|c|c|c|c|c|c|c|}
\hline $\begin{array}{l}\text { SNP } \\
\text { name }\end{array}$ & $\begin{array}{l}\text { Location } \\
\text { relative to } \\
\text { GH1 gene }\end{array}$ & $\begin{array}{c}\text { Nucleotide } \\
\text { position on } \\
\text { chromosome } \\
19^{1}(\mathrm{bp})\end{array}$ & $\begin{array}{l}\text { SNP alleles with flanking } \\
\text { nucleotide sequence }\end{array}$ & Genotype & $\begin{array}{l}\text { Genotype } \\
\text { frequency }\end{array}$ & MAF & HWE & Status & Reference $^{2}$ \\
\hline GH63 & $5^{\prime}$ & 49696441 & TGTGCTGGATTC[A/T]GTTTTGTTTTTA & $\begin{array}{l}\mathrm{A} / \mathrm{A} \\
\mathrm{A} / \mathrm{T} \\
\mathrm{T} / \mathrm{T}\end{array}$ & $\begin{array}{l}0.30 \\
0.50 \\
0.20\end{array}$ & 0.45 & 1.00 & dbSNP & rs41916256 \\
\hline GH32 & $5^{\prime}$ & 49693441 & GAAGCTTGGAGA[C/T]GGGAGCCCTAGT & $\begin{array}{l}\mathrm{C} / \mathrm{C} \\
\mathrm{C} / \mathrm{T} \\
\mathrm{T} / \mathrm{T}\end{array}$ & $\begin{array}{l}0.18 \\
0.46 \\
0.36\end{array}$ & 0.41 & 0.30 & Novel & ss196301608 \\
\hline GH35 & $5^{\prime}$ & 49693328 & CGCCTTGGTCAG[C/T]AGAGTCCTCTCS & $\begin{array}{l}\mathrm{C} / \mathrm{C} \\
\mathrm{C} / \mathrm{T} \\
\mathrm{T} / \mathrm{T}\end{array}$ & $\begin{array}{l}0.21 \\
0.48 \\
0.31\end{array}$ & 0.46 & 0.47 & dbSNP & rs41923522 \\
\hline GH38 & $5^{\prime}$ & 49693278 & GTAAASTGGGCA[C/T]GACTGTAGCACT & $\begin{array}{l}\mathrm{C} / \mathrm{C} \\
\mathrm{C} / \mathrm{T} \\
\mathrm{T} / \mathrm{T}\end{array}$ & $\begin{array}{l}0.26 \\
0.29 \\
0.45\end{array}$ & 0.40 & $4.6 \times 10^{-25}$ & dbSNP & rs41923525 \\
\hline 303 & $5^{\prime}$ & 49661919 & CTCAGTTGTGTC[C/T]GACCCTCAGYGA & $\begin{array}{l}\mathrm{C} / \mathrm{C} \\
\mathrm{C} / \mathrm{T} \\
\mathrm{T} / \mathrm{T}\end{array}$ & $\begin{array}{l}0.83 \\
0.17 \\
0.00\end{array}$ & 0.08 & 0.0037 & Published & $\begin{array}{l}r s 41923485 \\
\text { Ge et al. }(2003)\end{array}$ \\
\hline 2141 & Exon 5 & 49660275 & CCTTGGCAGGAG[C/G]TGGAAGATGGCA & $\begin{array}{l}\mathrm{C} / \mathrm{C} \\
\mathrm{C} / \mathrm{G}\end{array}$ & $\begin{array}{l}0.81 \\
0.16\end{array}$ & 0.10 & 0.0001 & Published & $\begin{array}{l}\text { rs41923484 } \\
\text { Zhang et al. (1992) } \\
\text { Lucy et al. (1993) } \\
\text { Yao et al. (1996) } \\
\text { Ge et al. (2003) }\end{array}$ \\
\hline 2291 & Exon 5 & 49660125 & GAGACGTACCTG[C/A]GGGTCATGAAGT & $\begin{array}{l}\mathrm{G} / \mathrm{G} \\
\mathrm{A} / \mathrm{A} \\
\mathrm{A} / \mathrm{C} \\
\mathrm{C} / \mathrm{C}\end{array}$ & $\begin{array}{l}0.03 \\
0.78 \\
0.20 \\
0.02\end{array}$ & 0.12 & 0.47 & Published & $\begin{array}{l}\text { Ge et al. } \\
\text { Yao et al. (1996) }\end{array}$ \\
\hline GH17 & $3^{\prime}$ & 49657371 & ATTTCAGAAACA[C/T]AAAACAAGTATC & $\begin{array}{l}\mathrm{C} / \mathrm{C} \\
\mathrm{C} / \mathrm{T} \\
\mathrm{T} / \mathrm{T}\end{array}$ & $\begin{array}{l}0.81 \\
0.17 \\
0.02\end{array}$ & 0.10 & 0.01 & dbSNP & rs41923483 \\
\hline GH19 & $3^{\prime}$ & 49657225 & TTTTAAAATCTC[C/T]GACTAAAATTGC & $\begin{array}{l}\mathrm{C} / \mathrm{C} \\
\mathrm{C} / \mathrm{T} \\
\mathrm{T} / \mathrm{T}\end{array}$ & $\begin{array}{l}0.02 \\
0.26 \\
0.72\end{array}$ & 0.15 & 0.86 & dbSNP & rs41923481 \\
\hline GH24 & $3^{\prime}$ & 49657093 & TCAGCAAATCTT[C/T]CTWAAAAGCTTT & $\begin{array}{l}\mathrm{C} / \mathrm{C} \\
\mathrm{C} / \mathrm{T} \\
\mathrm{T} / \mathrm{T}\end{array}$ & $\begin{array}{l}0.10 \\
0.15 \\
0.75\end{array}$ & 0.17 & $9.0 \times 10^{-27}$ & Novel & ss196003436 \\
\hline GH21 & $3^{\prime}$ & 49656852 & GGGAGTTCCTTC[G/A]TGGTGCAGTGGC & $\begin{array}{l}\mathrm{A} / \mathrm{A} \\
\mathrm{A} / \mathrm{G} \\
\mathrm{G} / \mathrm{G}\end{array}$ & $\begin{array}{l}0.78 \\
0.19 \\
0.03\end{array}$ & 0.13 & $7.9 \times 10^{-6}$ & dbSNP & rs41923479 \\
\hline
\end{tabular}


Table 3. Linkage disequilibrium (presented as $\mathrm{r}^{2}$ with $D^{\prime}$ in parentheses) between the segregating significant SNP in the population of 848 Holstein-Friesian cattle

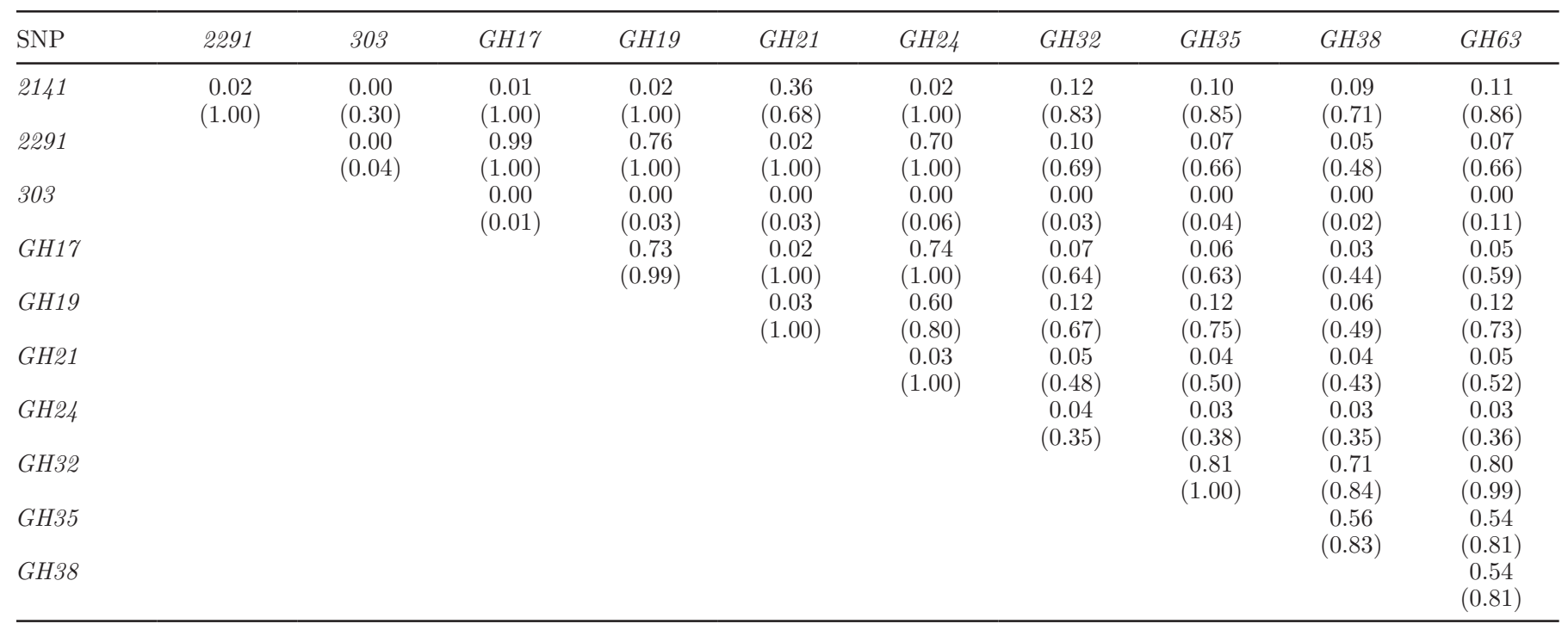

$<0.05)$ with animal stature $(P<0.05)$. Three SNP (GH21, 2291, and GH35) were independently associated $(P<0.05)$ with body depth. One SNP, GH19, in the $3^{\prime}$ UTR was associated $(P<0.05)$ with BCS. Two SNP, 303 and GH35, located in the 5' UTR were associated $(P<0.05)$ with angularity.

\section{Transcription Factor Binding Site Analysis}

The 5 SNP (303, GH32, GH35, GH38, and GH63) in the promoter region of $G H 1$ associated with production traits in the multiple regression model were examined for potential effects on transcription factor binding sites

Table 4. Allelic substitution effect (standard error in parentheses) between 11 SNP and milk production, SCS, survival, and body size and carcass traits in the Holstein-Friesian cattle population

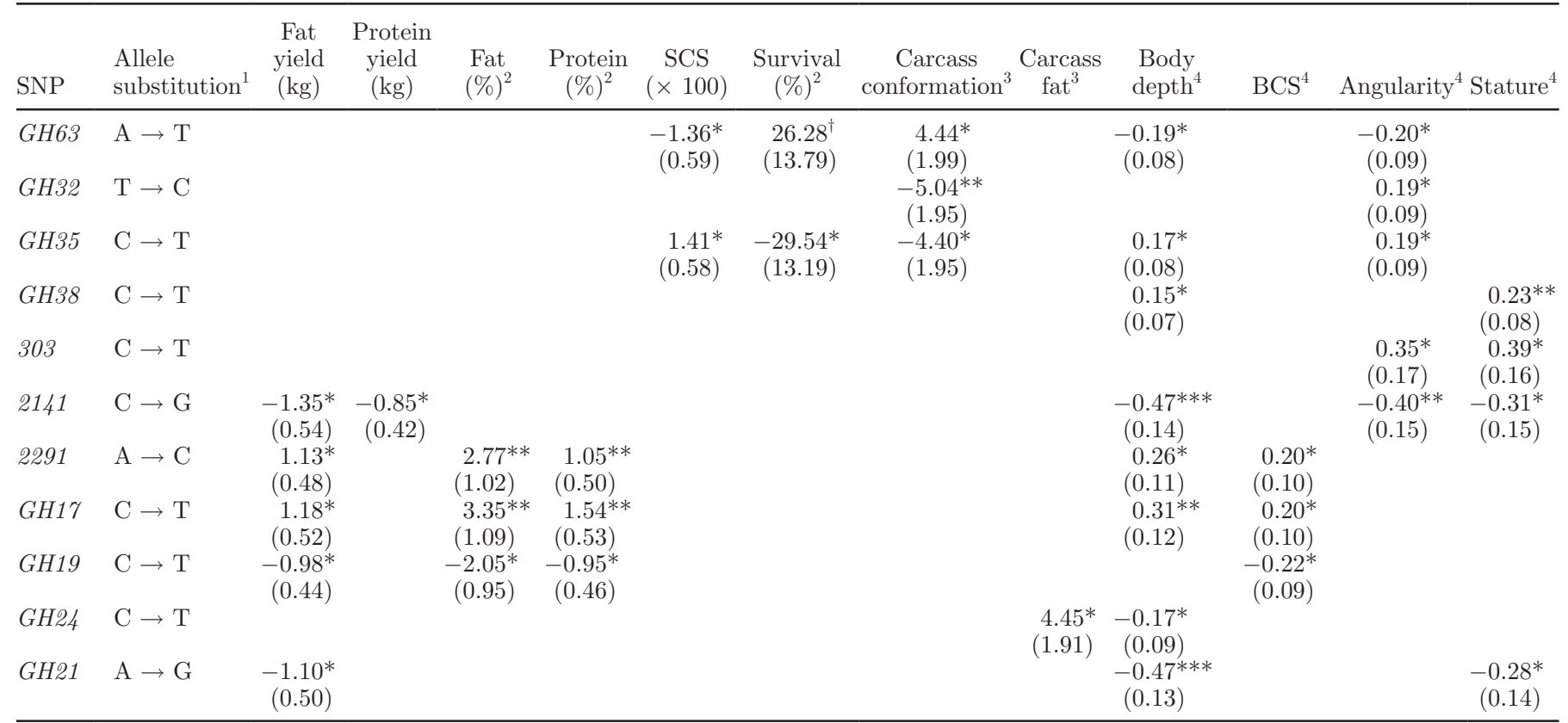

${ }^{1}$ Allele substitutions are reported from the minus strand of the growth hormone (GH1) gene.

${ }^{2} \mathrm{~A}$ value of 100 equates to 1 percentage unit.

${ }^{3}$ Carcass conformation measured on a scale from 100 (poor) to 1,500 (good); carcass fat measured on a scale from 100 (low) to 1,500 (high).

${ }^{4}$ Expressed in genetic standard deviation units

${ }^{*} P<0.05 ;{ }^{* *} P<0.01$; *** $P<0.001 ; \dagger P<0.1$. 
Table 5. Associations $(P<0.05$; SE in parentheses) between growth hormone (GH1) SNP and milk composition, survival, BCS, and carcass traits in Holstein-Friesian cattle when estimated using multiple regression models

\begin{tabular}{|c|c|c|c|c|c|c|c|c|c|c|c|c|c|}
\hline SNP & $\begin{array}{c}\text { Allele } \\
\text { substitution }\end{array}$ & $\begin{array}{l}\text { Fat yield } \\
(\mathrm{kg})\end{array}$ & $\begin{array}{l}\text { Protein } \\
\text { yield }(\mathrm{kg})\end{array}$ & $\begin{array}{l}\text { Fat } \\
\%^{3}\end{array}$ & $\begin{array}{c}\text { Protein } \\
\%^{3}\end{array}$ & $\begin{array}{c}\text { SCS } \\
(\times 100)\end{array}$ & $\begin{array}{c}\text { Survival }^{3} \\
(\%)\end{array}$ & $\begin{array}{c}\text { Carcass } \\
\text { conformation }\end{array}$ & $\begin{array}{c}\text { Carcass } \\
\text { fat }^{4}\end{array}$ & $\begin{array}{l}\text { Body } \\
\text { depth }^{5}\end{array}$ & $\mathrm{BCS}^{5}$ & Angularity $^{5}$ & Stature $^{5}$ \\
\hline GH63 & $\mathrm{A} \rightarrow \mathrm{T}$ & & & & & & & & $\begin{array}{c}4.45 \\
(1.84)\end{array}$ & & & & \\
\hline GH32 & $\mathrm{T} \rightarrow \mathrm{C}$ & & & & & & & $\begin{array}{c}-5.04 \\
(1.95)\end{array}$ & & & & & \\
\hline GH35 & $\mathrm{C} \rightarrow \mathrm{T}$ & & & & & $\begin{array}{c}2.03 \\
(0.62)\end{array}$ & $\begin{array}{c}-29.54 \\
(13.19)\end{array}$ & & & $\begin{array}{c}0.23 \\
(0.09)\end{array}$ & & $\begin{array}{c}0.19 \\
(0.09)\end{array}$ & \\
\hline GH38 & $\mathrm{C} \rightarrow \mathrm{T}$ & & & & & & & & & & & & $\begin{array}{c}0.23 \\
(0.08)\end{array}$ \\
\hline 303 & $\mathrm{C} \rightarrow \mathrm{T}$ & & & & & & & & & & & $\begin{array}{c}0.35 \\
(0.17)\end{array}$ & \\
\hline 2141 & $\mathrm{C} \rightarrow \mathrm{G}$ & & $\begin{array}{c}-0.85 \\
(0.42)\end{array}$ & & & & & & & & & & \\
\hline 2291 & $\mathrm{~A} \rightarrow \mathrm{C}$ & & & & & & & & & $\begin{array}{c}0.32 \\
(0.11)\end{array}$ & & & \\
\hline GH17 & $\mathrm{C} \rightarrow \mathrm{T}$ & & & $\begin{array}{c}3.35 \\
(1.09)\end{array}$ & $\begin{array}{c}1.54 \\
(0.53)\end{array}$ & & & & & & & & \\
\hline GH19 & $\mathrm{C} \rightarrow \mathrm{T}$ & $\begin{array}{c}-0.98 \\
(0.44)\end{array}$ & & & & & & & & & $\begin{array}{c}-0.22 \\
(0.09)\end{array}$ & & \\
\hline $\mathrm{GH}_{24}$ & $\mathrm{C} \rightarrow \mathrm{T}$ & & & & & $\begin{array}{c}-1.54 \\
(0.64)\end{array}$ & & & $\begin{array}{c}5.44 \\
(1.99)\end{array}$ & & & & \\
\hline GH21 & $\mathrm{A} \rightarrow \mathrm{G}$ & & & & & & & & & $\begin{array}{c}-0.45 \\
(0.13)\end{array}$ & & & \\
\hline
\end{tabular}

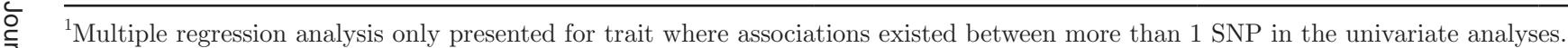

2Allele substitutions are reported from the minus strand of the growth hormone (GH1) gene.

$\stackrel{3}{\longrightarrow}$ A value of 100 equates to 1 percentage unit.

ㄱ. ${ }^{4}$ Carcass conformation measured on a scale from 100 (poor) to 1,500 (good); carcass fat measured on a scale from 100 (low) to 1,500 (high).

Expressed in genetic standard deviation units. 
(TFBS). Analysis of TFBS in silico predicted that 3 promoter SNP (303, GH35 and GH38) affect transcription factor (TF) binding, as shown in Table 6 .

Both alleles of 303 were predicted to introduce differential binding sites for TF including twist subfamily of class B basic helix loop helix (bHLH) transcription factors, vertebrate SMAD family of transcription factors, and paired box protein 5 (PAX-5) B-cell-specific activator protein binding sites. In contrast, the $\mathrm{T}$ allele of GH35 abrogated 2 predicted TF binding sites for musculoaponeurotic fibrosarcoma oncogene (MAF)/ activator protein 1 (AP1) and retinoid $\mathrm{X}$ receptor (RXR) heterodimers observed when the $\mathrm{C}$ allele is present. Both alleles of GH38 introduce single differential TFBS for general transcription factor IID (GTF2D) and p53 tumor suppressor.

\section{MicroRNA Analysis}

Four SNP, GH17, GH19, GH21 and GH24, in the 3' UTR of GH1 associated with production traits in the multiple regression model were analyzed for their potential effects on micro(mi)RNA binding sites. Analysis of miRNA sites in silico predicted that two $3^{\prime}$ UTR SNP, GH21 and GH24, affect miRNA binding (Table 7). Both alleles of GH21 introduce several different miRNA sites, whereas the C allele of GH24 introduces a miRNA binding site that is abrogated in the presence of the $\mathrm{T}$ allele.

\section{DISCUSSION}

The current candidate gene study identified both novel and previously reported SNP located within the 5' UTR, exonic, intronic, and 3' UTR of the bovine GH1 gene. Eleven of these SNP were found to be associated with genetic merit for economically important traits. Although, following adjustment for multiple testing, only 2 SNP remained associated $(P<0.05)$ with performance, identification of patterns and clusters of associations between adjacent SNP, as well as results from the multiple regression analysis, could provide useful information into regions of the genes that may be associated with performance. The allele frequencies of the SNP included in the multiple regression models varied from 0.08 to 0.46 and these frequencies could have contributed to whether or not the SNP was included in the multiple regression model. Nonetheless, the undertaking of many statistical tests can lead to the realization of Type I errors.

Only 26 out of the 63 originally identified SNP were included in the association analysis because of a lack of segregation, design failures of the in silico probes, or poor call rates. However, all 63 SNP were accurately

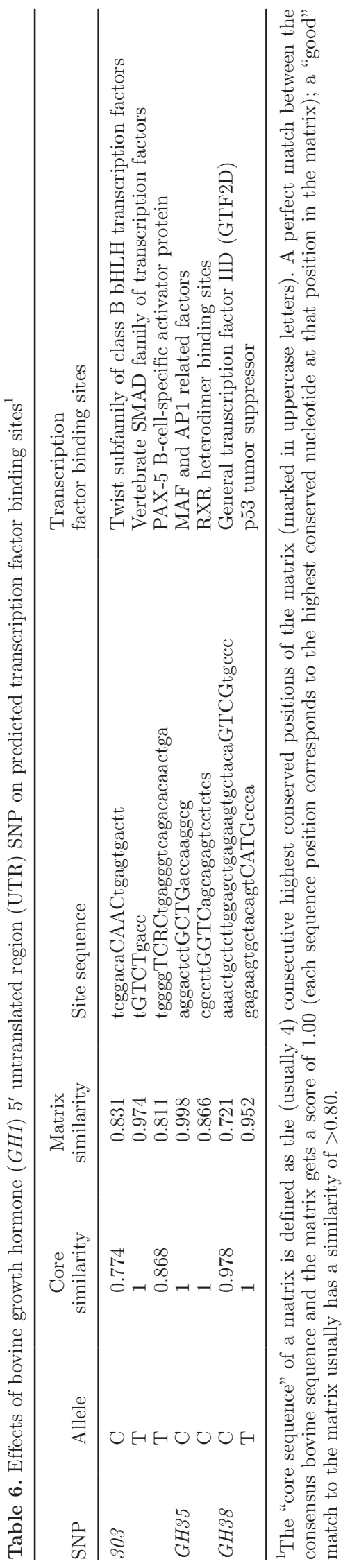


Table 7. Effects of bovine growth hormone (GH1) 3' untranslated region (UTR) SNP on micro-(mi)RNA binding sites ${ }^{1}$

\begin{tabular}{llllc}
\hline SNP & Allele & miRNA & $\begin{array}{l}\text { miRNA } \\
\text { name }\end{array}$ & $\begin{array}{c}\text { Free energy } \Delta G \\
(\mathrm{kcal} / \mathrm{mol})\end{array}$ \\
\hline SH21 & $\mathrm{G}$ & bta-miR-151-star & ucgaggagcucacagucuagu & -24.2 \\
& $\mathrm{G}$ & bta-miR-1306 & ccaccuccccugcaaacgucc & -25.3 \\
& $\mathrm{~A}$ & bta-miR-17-3p & acugcagugaaggcacuugu & -23.7 \\
& $\mathrm{~A}$ & bta-miR-220a & ccacgaccgugucugacaccuu & -21.8 \\
& $\mathrm{~A}$ & bta-miR-92b & uaungcacucgucccggccucc & -22.9 \\
& $\mathrm{~A}$ & bta-miR-220d & ccaccaccgugucugacaccu & -23.1 \\
GH24 & $\mathrm{A}$ & bta-miR-220c & ccaccaccgugucggacaccuu & -27.0 \\
\hline
\end{tabular}

${ }^{1}$ Free energy: Gibbs free energy $(\Delta G)$ of the duplex structure is indicated.

identified in the sequence data from the 22 cattle SNP discovery cattle panel, by manual inspection of each sequence chromatogram and may represent rare variants. Additionally, 4 breeds other than Holstein-Friesian contributed to the panel, which would account for the lack of segregation in the cohort of Holstein-Friesian AI bulls. Furthermore, high variability and repetitive regions observed during this study within GH1 have previously been reported by Hecht and Geldermann (1996) and by Yao et al. (1996), which would account for in silico design failures and poor call rates. The quality of the DNA did not contribute to the low call rates because genotyping and association analyses simultaneously undertaken by this group using the Sequenom MassArray iPLEX Gold assay and the same DNA aliquots achieved high call rates (Waters et al., 2010).

\section{5' UTR SNP}

Of the 5 significant $5^{\prime}$ UTR SNP, 3 (303, GH35, and GH38) were predicted to modulate TFBS. Although previous studies by Ge et al. (2003) failed to identify an association between 303 (SNP GH1), 253 (SNP GH2), or 313 (SNP GH3) and either growth traits or plasma IGF-1 levels in 468 Angus cattle, the T allele of 303 in the current study was associated with increased angularity. Interestingly, in silico analysis predicted several effects of 303 on TFBS including the introduction or abrogation of binding sites for the twist subfamily of class B bHLH transcription factors. The twist subfamily of class B bHLH transcription factors, which have been shown in vitro to be tissue specific (Lassar et al., 1991), play a key role in muscle gene expression (Olson and Klein, 1994). Interestingly, 303 was predicted to affect TFBS for PAX-5 B-cell-specific activator proteins, which have been shown to be involved in the regulation of chromatin remodeling in the CD19 locus in mice (Walter et al., 2008) and thereby potentially controlling access to the promoter region of GH1.
In silico analysis revealed that the C allele of $G H 35$, which was associated with several traits in the present study, introduced pTFBS for MAF/AP-1 related factors and RXR heterodimers. Activator protein-1 mediates many mammalian cell physiological processes and was previously shown to be involved in transcriptional regulation of the chicken $I G F-1$ gene (Umayahara et al., 1994), whereas RXR heterodimers modify chromatin structure within the promoter region and recruit transcriptional machinery to initiate transcription (Hebbar and Archer, 2003). The SNP GH38, which was associated with stature, altered 2 pTFBS; first, that for GTF2D, found to be involved in transcriptional regulation of hepatic genes in mice (Tatarakis et al., 2008); and second, that for p53 tumor suppressor, which in part functions as a transcriptional activator of many target genes, including IGFBP3, which modulates the mitogenic effects of $I G F-1$ (Buckbinder et al., 1995). Both GH32 and GH63 were associated with carcass fat and conformation but were not predicted to affect TFBS directly and may mediate effects through LD with proximal causative variant(s), which could include GH35, GH38, or both. Although we provide a biological rationale for the possible mechanisms of the associations with 303, GH35, and GH38, the observed associations could be caused by other mutations in LD with these SNP. Interestingly, univariate analysis of GH32, GH35, GH38, and GH63 showed clustering of either 2 or 3 associations per trait. These SNP were in moderate to high LD, within $3.2 \mathrm{~kb}$ of each other, and associated with SCS, carcass conformation, body depth, and angularity, suggesting that mutations in LD or within with the $5^{\prime}$ UTR region of GH1 have direct effects on production traits in cattle.

\section{Exonic SNP}

The most extensively reported GH1 polymorphism in the literature is the $\mathrm{C}$ to $\mathrm{G}$ nucleotide transversion at position 2141 of GH1 (Gordon et al., 1983) reported 
by Yao et al. (1996), Zhang et al. (1992), and Lucy et al. (1993), resulting in a Leu (C allele) to Val ( $\mathrm{G}$ allele) substitution at residue 127 of the GH polypeptide. Other studies (Lee et al., 1993; Lucy et al., 1993) corroborated the observed negative associations between the Val bovine growth hormone variant and milk production in the present study. Furthermore, Vukasinovic et al. (1999) reported an allele substitution effect of 2141 and milk protein percentage in Holstein cows. Lechniak et al. (1999) failed to identify an association between 2141 and reproductive traits in dairy cows, which is in agreement with our findings. Although Grochowska et al. (1999) reported no association between 2141 and thyrotropin-releasing hormone-induced GH release, they suggested that the 2141 SNP may affect pituitary secretion. Additionally, evidence exists that the Val ( $\mathrm{G}$ allele) variant of 2141 is associated with serum GH levels; a study by Schlee et al. (1994) in German Black and White bulls showed that homozygous Leu carriers had higher plasma GH than did heterozygote contemporaries. In contrast to the numerous studies that explored possible associations between 2141 and milk production, fewer studies have attempted to relate the $2141 \mathrm{SNP}$ and growth traits in cattle. In the present study, the Val variant ( $G$ allele) was associated with shorter, narrower, thinner animals, which would be consistent with the findings of increased carcass meat and overall carcass weight observed for the $\mathrm{C}$ allele by Grochowska et al. (2001) in 109 Polish Friesian bulls, increased muscularity and adiposity observed with 2141 heterozygotes in 186 Brangus bulls by Thomas et al. (2007), and increased carcass weight observed in Japanese black cattle carrying the $\mathrm{C}$ allele reported by Tatsuda et al. (2008).

\section{3' UTR SNP}

Limited information is available on the effects of the introduction or abrogation of miRNA binding sites on genes involved in growth, postnatal development, and production traits in cattle. However, miRNA are well established as posttranscriptional gene expression regulators and are thought to regulate as many as 5,300 human genes (Lewis et al., 2005).

Of the four 3' UTR SNP associated with milk production and body size traits in the present study, none have previously been tested for associations with production traits in cattle. In silico analysis predicted that GH21 and GH24 affect several miRNA binding sites that might regulate $\mathrm{GH}$ protein synthesis. The $\mathrm{C}$ allele of GH24 introduced a miRNA site for bta-miR-671; however, limited information is available on its biological effects. Both alleles of GH21 introduced multiple different miRNA binding sites, including bta-miR-1306 and bta-miR-17-3. Three of the SNP (GH1\%, GH19, and GH24) were in moderate to high LD, all within $520 \mathrm{bp}$, and therefore the effects observed by GH17 and GH19 may be due to LD with GH24, or indeed a different mutation. Additionally, GH17, GH19, and an exonic SNP, 2291, also in strong LD were associated as a cluster with milk fat and protein percentages and milk fat yield under univariate analysis, strongly supporting the hypothesis that a mutation in LD or within this region of the GH1 gene effects milk production.

\section{CONCLUSIONS}

The complex role of GH in postnatal growth and development is facilitated by tissue-specific interactions, which in part are proposed to be due to heterogeneous forms of GH in vivo. The extent to which polymorphisms in GH1 contribute to these variants has yet to be determined. Whether the associations observed in this study are due to functional effects of these SNP is unknown; they may be due to LD with causative polymorphisms yet undetected in bovine GH1 or nearby regions of the genome. Future work could include resequencing of the complete bovine GH1 gene, its alternate transcript, and its transcriptional regulators in animals divergent for traits of economic importance. This approach could identify potential causative polymorphisms, which if augmented with functional genomic studies and validated in independent populations of cattle, would yield greater insight into the influence of variants of $G H 1$ on performance.

\section{ACKNOWLEDGMENTS}

The authors acknowledge the Irish Cattle Breeding Federation (ICBF, Bandon, Co. Cork, Ireland) for access to estimates of sire merit. Research funding was provided by the Irish Dairy Research Trust, the Department of Agriculture, Fisheries and Food Research Stimulus Fund (Dublin, Ireland; RSF-06-0353; RSF06-0409; RSF-06-406), Investigator Programme Grant, and Strategic Research Grant from Science Foundation Ireland (Dublin, Ireland; SFI/01/F.1/B028; 07/SRC/ B1156).

\section{REFERENCES}

Banos, G., J. A. Woolliams, B. W. Woodward, A. B. Forbes, and M. P. Coffey. 2008. Impact of single nucleotide polymorphisms in leptin, leptin receptor, growth hormone receptor, and diacylglycerol acyltransferase (DGAT1) gene loci on milk production, feed, and body energy traits of UK dairy cows. J. Dairy Sci. 91:3190-3200.

Bauman, D. E. 1992. Bovine somatotropin: Review of an emerging animal technology. J. Dairy Sci. 75:3432-3451.

Berry, D., F. Kearney, and B. Harris. 2009. Genomic selection in Ireland. Proc. Interbull International Workshop. Interbull, Uppsala, Sweden. 
Berry, D. P., L. Shalloo, A. R. Cromie, R. F. Veerkamp, P. Dillion, and P. R. Am. J. F. Kearney, R. D. Evans, and B. Wickham. 2007. The economic breeding index: A generation on. Irish Cattle Breeding Federation, Bandon, Co. Cork, Ireland.

Buckbinder, L., R. Talbott, S. Velasco-Miguel, I. Takenaka, B. Faha, B. R. Seizinger, and N. Kley. 1995. Induction of the growth inhibitor IGF-binding protein 3 by p53. Nature 377:646-649.

Cartharius, K., K. Frech, K. Grote, B. Klocke, M. Haltmeier, A. Klingenhoff, M. Frisch, M. Bayerlein, and T. Werner. 2005. MatInspector and beyond: Promoter analysis based on transcription factor binding sites. Bioinformatics 21:2933-2942.

Ge, W., M. E. Davis, H. C. Hines, K. M. Irvin, and R. C. M. Simmen. 2003. Association of single nucleotide polymorphisms in the growth hormone and growth hormone receptor genes with blood serum insulin-like growth factor I concentration and growth traits in Angus cattle. J. Anim. Sci. 81:641-648.

Gilmour, A. R., B. R. Cullis, S. J. Welham, and R. Thompson. 2009. ASREML Reference Manual. 2nd ed. New South Wales Agriculture, Orange Agricultural Institute, Orange, NSW, Australia.

Gordon, D. F., D. P. Quick, C. R. Erwin, J. E. Donelson, and R. A. Maurer. 1983. Nucleotide sequence of the bovine growth hormone chromosomal gene. Mol. Cell. Endocrinol. 33:81-95.

Grochowska, R., P. Sorensen, L. Zwierzchowski, M. Snochowski, and P. Lovendahl. 2001. Genetic variation in stimulated GH release and in IGF-I of young dairy cattle and their associations with the leucine/valine polymorphism in the GH gene. J. Anim. Sci. 79:470-476.

Grochowska, R., L. Zwierzchowski, M. Snochowski, and Z. Reklewski. 1999. Stimulated growth hormone (GH) release in Friesian cattle with respect to GH genotypes. Reprod. Nutr. Dev. 39:171-180.

Hebbar, P. B., and T. K. Archer. 2003. Chromatin remodeling by nuclear receptors. Chromosoma 111:495-504.

Hecht, C., and H. Geldermann. 1996. Variants within the 5'-flanking region and the intron I of the bovine growth hormone gene. Anim. Genet. 27:329-332.

Heyen, D. W.. J. E. Beever, Y. Da, R. E. Evert, C. Green, S. E. R. Bates, J. S. Ziegle, and H. A. Lewin. 1997. Exclusion probabilities of 22 bovine microsatellite markers in fluorescent multiplexes for semiautomated parentage testing . Anim. Genet. 28:21-27.

Jiang, H., and M. C. Lucy. 2001. Variants of the 5 '-untranslated region of the bovine growth hormone receptor mRNA: Isolation, expression and effects on translational efficiency. Gene 265:45-53.

Lagziel, A., and M. Soller. 1999. DNA sequence of SSCP haplotypes at the bovine growth hormone (bGH) gene. Anim. Genet. 30:362365 .

Larkin, M. A., G. Blackshields, N. P. Brown, R. Chenna, P. A. McGettigan, H. McWilliam, F. Valentin, I. M. Wallace, A. Wilm, R. Lopez, J. D. Thompson, T. J. Gibson, and D. G. Higgins. 2007. Clustal W and Clustal X version 2.0. Bioinformatics 23:29472948.

Lassar, A. B., R. L. Davis, W. E. Wright, T. Kadesch, C. Murre, A. Voronova, D. Baltimore, and H. Weintraub. 1991. Functional activity of myogenic HLH proteins requires hetero-oligomerization with E12/E47-like proteins in vivo. Cell 66:305-315.

Lechniak, D., G. Machnik, M. Szydlowski, and M. Switonski. 1999. Growth hormone gene polymorphism and reproductive performance of AI bulls. Theriogenology 52:1145-1152.

Lee, B. K., G. F. Lin, B. A. Crooker, M. P. Murtaugh, L. B. Hansen, and H. Chester-Jones. 1993. Association of somatotropin (bST) gene polymorphism with selection for milk yield in Holstein cows J. Dairy Sci. 76(Suppl. 1):149. (Abstr.)

Lewis, B. P., C. B. Burge, and D. P. Bartel. 2005. Conserved seed pairing, often flanked by adenosines, indicates that thousands of human genes are microRNA targets. Cell 120:15-20.
Lucy, M. C. 2008. Functional differences in the growth hormone and insulin-like growth factor axis in cattle and pigs: Implications for post-partum nutrition and reproduction. Reprod. Domest. Anim. 43(Suppl. 2):31-39.

Lucy, M. C., S. D. Hauser, P. J. Eppard, G. G. Krivi, J. H. Clark, D. E. Bauman, and R. J. Collier. 1993. Variants of somatotropin in cattle: Gene frequencies in major dairy breeds and associated milk production. Domest. Anim. Endocrinol. 10:325-333.

Montgomery, G. W., and J. A. Sise. 1990. Extraction of DNA from sheep white blood cells. N. Z. J. Agric. Res. 33:437-441.

Olson, E. N., and W. H. Klein. 1994. bHLH factors in muscle development: Dead lines and commitments, what to leave in and what to leave out. Genes Dev. 8:1-8.

Renaville, R., M. Hammadi, and D. Portetelle. 2002. Role of the somatotropic axis in the mammalian metabolism. Domest. Anim. Endocrinol. 23:351-360

Rusinov, V., V. Baev, I. N. Minkov, and M. Tabler. 2005. MicroInspector: A web tool for detection of miRNA binding sites in an RNA sequence. Nucleic Acids Res. 33(Web Server issue):W696-700.

Schlee, P. R. Graml, E. Schallenberger, D. Schams, O. Rottmann, A. Olbrich-Bludau, and F. Pirchner. 1994. Growth hormone and insulin-like growth factor I concentrations in bulls of various growth hormone genotypes. Theor. Appl. Genet. 88:497-500.

Skaletsky, S. R. H. J. 2000. Primer3 on the WWW for general users and for biologist programmers. Bioinformatics Methods and Protocols: Methods in Molecular Biology. Humana Press, Totowa, NJ.

Tatarakis, A., T. Margaritis, C. P. Martinez-Jimenez, A. Kouskouti, W. S. Mohan Ii, A. Haroniti, D. Kafetzopoulos, L. Tora, and I. Talianidis. 2008. Dominant and redundant functions of TFIID involved in the regulation of hepatic genes. Mol. Cell 31:531-543.

Tatsuda, K., A. Oka, E. Iwamoto, Y. Kuroda, H. Takeshita, H. Katao$\mathrm{ka}$, and S. Kouno. 2008. Relationship of the bovine growth hormone gene to carcass traits in Japanese black cattle. J. Anim. Breed. Genet. 125:45-49

Thomas, M. G., R. M. Enns, K. L. Shirley, M. D. Garcia, A. J. Garrett, and G. A. Silver. 2007. Associations of DNA polymorphisms in growth hormone and its transcriptional regulators with growth and carcass traits in two populations of Brangus bulls. Genet. Mol. Res. 6:222-237.

Umayahara, Y., R. Kawamori, H. Watada, E. Imano, N. Iwama, T. Morishima, Y. Yamasaki, Y. Kajimoto, and T. Kamada. 1994. Estrogen regulation of the insulin-like growth factor I gene transcription involves an AP-1 enhancer. J. Biol. Chem. 269:1643316442 .

Vukasinovic, N., S. K. Denise, and A. E. Freeman. 1999. Association of growth hormone loci with milk yield traits in Holstein bulls. J. Dairy Sci. 82:788-794.

Walter, K., C. Bonifer, and H. Tagoh. 2008. Stem cell-specific epigenetic priming and $\mathrm{B}$ cell-specific transcriptional activation at the mouse Cd19 locus. Blood 112:1673-1682.

Waters, S. M., M. S. McCabe, D. J. Howard, L. Giblin, D. A. Magee, D. E. MacHugh, and D. P. Berry. 2010. Associations between newly discovered polymorphisms in the Bos taurus growth hormone receptor gene and performance traits in Holstein-Friesian dairy cattle . Anim. Genet. Epub ahead of print.

Yao, J., S. E. Aggrey, D. Zadworny, J. F. Hayes, and U. Kuhnlein. 1996. Sequence variations in the bovine growth hormone gene characterized by single-strand conformation polymorphism (SSCP) analysis and their association with milk production traits in Holsteins. Genetics 144:1809-1816.

Zhang, H. M., D. R. Brown, S. K. Denise, and R. L. Ax. 1992. Nucleotide sequence determination of a bovine somatotropin allele. Anim. Genet. 23:578. 